\title{
Ethylene Signaling Mediates a Maize Defense Response to Insect Herbivory
}

\author{
Antoine L. Harfouche, ${ }^{1}$ Renuka Shivaji, ${ }^{1}$ Russell Stocker, ${ }^{2}$ Paul W. Williams, ${ }^{3}$ and Dawn S. Luthe ${ }^{1}$ \\ ${ }^{1}$ Department of Biochemistry and Molecular Biology, Box 9650, Mississippi State University, MS 39762, U.S.A.; \\ ${ }^{2}$ Department of Mathematics and Statistics, Box 9715, Mississippi State University, MS 39762, U.S.A.; ${ }^{3}$ USDA, ARS, \\ Corn Host Plant Resistant Unit, Box 5367, Mississippi State, MS 39762, U.S.A.
}

Submitted 18 May 2005. Accepted 6 October 2005.

\begin{abstract}
The signaling pathways that enable plants to mount defenses against insect herbivores are known to be complex. It was previously demonstrated that the insect-resistant maize (Zea mays L.) genotype Mp708 accumulates a unique defense cysteine proteinase, Mir1-CP, in response to caterpillar feeding. In this study, the role of ethylene in insect defense in Mp708 and an insect-susceptible line Tx601 was explored. Ethylene synthesis was blocked with either cobalt chloride or aminoethoxyvinylglycine. Alternatively, ethylene perception was inhibited with 1-methylcyclopropene. Blocking ethylene synthesis and perception resulted in Mp708 plants that were more susceptible to caterpillar feeding. In addition, fall armyworm (Spodoptera frugiperda) larvae that fed on inhibitor-treated Mp708 plants had signifycantly higher growth rates than those reared on untreated plants. In contrast, these responses were not significantly altered in Tx601. The ethylene synthesis and perception inhibitors also reduced the accumulation of Mir1-CP and its transcript mirl in response to herbivory. These results indicate that ethylene is a component of the signal transduction pathway leading to defense against insect herbivory in the resistant genotype $\mathrm{Mp708}$.
\end{abstract}

In their natural habitat, plants encounter multiple biotic and abiotic challenges simultaneously. Each environmental stress activates multiple signal transduction pathways to ensure an effective spatial and temporal defense response (Dempsey and Klessig 1999; Genoud and Métraux 1999; Pieterse and van Loon 1999; Ryan 2000). Therefore, plants must be able to identify and prioritize each signaling pathway to mount the most efficacious defense to minimize damage and preserve vegetative growth and reproductive success (Karban and Baldwin 1997). To protect themselves from pathogen and herbivore attack, plants use constitutive and induced defenses. These defenses can influence herbivore settling, feeding, oviposition, growth and development, fecundity, and fertility, either singly or together (Baldwin and Preston 1999).

A novel insect defense mechanism in maize (Zea mays) genotypes that have genetic resistance to feeding by fall armyworm (FAW, Spodoptera frugiperda) and a number of other Lepidopteran species has previously been identified (Pechan et al. 2000). In the field, these resistant lines (Mp704, Mp708)

Corresponding author: Dawn S. Luthe; E-mail: dsluthe@ra.msstate.edu; Telephone:, +1.662.325.7733; Fax: +1.662.325.8664.

Current address of A. L. Harfouche: Center for Environmental Stress Physiology, 625 Agricultural Mall Drive, Purdue University, West Lafayette, IN 47907, U.S.A. exhibit less foliar damage than the susceptible line (Tx601) and caterpillars that feed on the resistant plants are significantly smaller than those that feed on the susceptible lines (Williams et al. 1989). In response to caterpillar feeding, a unique $33-\mathrm{kDa}$ cysteine proteinase (Mir1-CP), encoded by mirl, accumulates in the whorls of resistant lines Mp704 and Mp708. Ectopic expression of mirl in Black Mexican Sweet cells indicated that Mir1-CP inhibited caterpillar growth by as much as $80 \%$ (Pechan et al. 1999, 2000). When caterpillars ingest Mir1-CP, it attacks their peritrophic matrix, a structure that surrounds the food bolus and protects the intestinal microvilli from toxins and mechanical damage (Pechan et al. 2002). These studies indicate how Mir1-CP affects the digestive system of the insect herbivore, but information about the signaling pathways involved in Mir1-CP accumulation is virtually nonexistent.

The plant hormone ethylene plays important roles in plant defense (Dong 1998; Guo and Ecker 2004; Kende 1993; Wang et al. 2002). Insect herbivory is known to promote an increase in jasmonic acid (JA) accumulation and ethylene emission (Argandona et al. 2001; Schmelz et al. 2003). One of the primary effects of ethylene is to alter the expression of various target genes. In some plants, ethylene increases transcript levels of defense-related genes, including chitinase and $\beta-1,3$ glucanase (Shinshi et al. 1995; Wu and Bradford 2003), peroxidase (Ishige et al. 1993), chalcone synthase (Ecker and Davis 1987), pathogenisis-related (PR) genes (Lawton et al. 1994), ripening-related genes (Zegzouti et al. 1999), ethylene biosynthesis genes, as well as cysteine proteinase genes (Cervantes et al. 1994; Jones et al. 1995). However, in Nicotiana attenuata, ethylene suppresses defense against Manduca sexta by lowering the putresine amino transferase transcripts in the root and nicotine levels in the shoot (Winz and Baldwin 2001).

In addition to herbivory, ethylene is involved in pathogen defense and its effect varies dramatically, depending on the type of pathogen and plant species. For example, in soybean, mutants with reduced ethylene sensitivity produce less severe chlorotic symptoms when challenged with the virulent strains Pseudomonas syringae pv. glycinea and Phytophthora sojae, whereas virulent strains of the fungi Septoria glycines and Rhizoctonia solani cause more severe symptoms (Hoffman et al. 1999). Similarly, in Arabidopsis, the ethylene-insensitive mutant ein 2 develops only minimal disease symptoms as the result of enhanced disease tolerance when infected by virulent $P$. syringae pv. tomato or Xanthomonas campestris pv. campestris (Bent et al. 1992). Ethylene also plays a role in genefor-gene resistance between tomato and $P$. syringae pv. tomato. Transcription of Pti4, which is regulated by the activity of the resistance gene Pto, is rapidly induced by ethylene, and this 
induction precedes the expression of $P R$ genes $(\mathrm{Gu}$ et al. 2000). Other research showed that ethylene may also function independently or with salicylic acid and JA in the activation of the hypersensitive response, which triggers a long-lasting response known as systemic acquired resistance to provide immunity against subsequent infections caused by a broad spectrum of pathogens. Arabidopsis plants with defects in ethylene perception (ein2) or JA signaling (coil) fail to induce a subset of $P R$ gene expression, including the plant defensin gene $P D F 1.2$, a basic chitinase $(P R-3)$, and an acidic hevein-like protein $(P R-4)$, resulting in enhanced susceptibility toward certain pathogens (Penninckx et al. 1998). One of the more intriguing aspects of the induction of PDF1.2 is that it requires both intact JA and ethylene signaling, whereas the majority of other responses mediated by these hormones are specific to only one of the signals. Likewise, it has been shown that both ethylene and JA are required for protease inhibitor (pin) production in response to wounding in tomato (O'Donnell et al. 1996). The pathway of ethylene synthesis is well established in higher plants (Bleecker and Kende 2000). Ethylene is formed from methionine via $S$-adenosyl-L-methionine (AdoMet) and the cyclic nonprotein amino acid 1-aminocyclopropane-1-carboxylic acid (ACC). ACC is formed from AdoMet by the action of ACC synthase (ACS), and the conversion of ACC to ethylene is carried out by ACC oxidase (ACO) (Kende 1993). After synthesis, ethylene is perceived and its signal transduced through cellular machinery to trigger specific biological responses. Ethylene is perceived by a family of membrane-localized receptors that are homologous to bacterial two-component histidine kinases involved in sensing environmental changes. In Arabiodpsis, five ethylene receptors exist, ETR1, ETR2, ERS1, ERS2, and EIN4 (Chang et al. 1993; Hua and Meyerowitz 1998; Hua et al. 1995; Sakai et al. 1998).

The physiological effects of ethylene can be blocked by biosynthesis inhibitors or antagonists. Chemical compounds such as aminoethoxyvinylglycine (AVG) and cobalt chloride $\left(\mathrm{CoCl}_{2}\right)$ inhibit the synthesis of ethylene. The former blocks the rate-limiting step of the ethylene biosynthesis pathway, which is the conversion of AdoMet to ACC by inhibiting ACS (Amrhein and Wenker 1979), whereas the latter blocks the conversion of ACC to ethylene by inhibiting ACO (Lau and Yang 1976). For ethylene to have an effect, it must first bind the ethylene receptors on the cell surface. 1-Methylcyclopropane $(1-\mathrm{MCP})$ is a compound that blocks ethylene signaling by irreversibly binding to these receptors (Sisler and Serek 1997).

Because mutants in the ethylene signaling pathway are not readily available in maize, resistant (Mp708) and susceptible (Tx601) maize plants were treated with chemicals that block ethylene synthesis and perception, and their effects on herbivory, insect growth, and the accumulation of Mir1-CP and mirl mRNA were determined. The results indicate that blocking the ethylene pathway makes the resistant plants significantly more susceptible to herbivory and retards the accumulation of the mirl transcript and Mir1-CP.

\section{RESULTS}

Ethylene inhibitors increase leaf damage and larval growth in response to larval feeding in resistant but not in susceptible maize genotypes.

Initial experiments were conducted to determine if ethylene was involved in the defense signaling pathway leading to Mir1$\mathrm{CP}$ accumulation in the resistant maize genotype Mp708 in response to FAW feeding. Plants were treated with the ethylenegenerating compound, ethephon (Laudert and Weiler 1998), or were incubated in a chamber with a ripening banana (Chao et al. 1999). Neither treatment induced the accumulation of Mir1-CP (data not shown). Other exploratory experiments indicated that blocking ethylene perception with 1-MCP reduced the accumulation of Mir1-CP and resulted in greater leaf feeding damage. To extend these preliminary observations, a pharmacological approach was used to block ethylene synthesis or perception in the resistant (Mp708) and susceptible (Tx601) maize genotypes, and the subsequent plant response to FAW feeding was determined. Plants were pretreated for $24 \mathrm{~h}$ with the ethylene synthesis inhibitors AVG or $\mathrm{CoCl}_{2}$, which inhibit ACS and ACO activity, respectively. Plants were then infested with FAW larvae, and the effects of the treatments on leaf damage and larval relative growth rates (RGR) were determined. When compared with water-treated controls, a 24-h pretreatment with AVG or $\mathrm{CoCl}_{2}$ significantly increased the level of leaf damage after 8,24 , and $48 \mathrm{~h}$ of larval feeding in Mp708 $(P<0.0001$; Fig. 1A). There was no significant difference between AVG- and $\mathrm{CoCl}_{2}$-treated plants $(P=0.8983)$. In addition, there was no interaction between treatment versus time $(P=0.6988)$, which indicated that the difference between water-treated controls and AVG- and $\mathrm{CoCl}_{2}$-treated plants remained constant over time. Tx601 plants showed an interaction with time when leaf damage was evaluated. Therefore, the differences between water-treated controls and AVG- and $\mathrm{CoCl}_{2}$-treated plants depended on the time. There were no significant increases in leaf damage when Tx601 was treated with the same inhibitors of ethylene biosynthesis at $8 \mathrm{~h}$ $(P=0.9996, P=1.000)$ or $48 \mathrm{~h}(P=0.9999, P=0.9907)$ (Fig. $1 \mathrm{C})$. However, at $24 \mathrm{~h}$ there was a small increase in leaf damage in the $\mathrm{CoCl}_{2}$-treated plants relative to the control $(P=0.0309$; Fig. 1C), and there was a significant increase in leaf damage between the AVG-treated plants and the control $(P=0.0004$; Fig. 1C). Although the standard error bars overlap at this timepoint, Tukey's statistical adjustment indicates that these differences are significant.

Plants were also pretreated for $24 \mathrm{~h}$ with the ethylene antagonist 1-MCP. At 24 and $48 \mathrm{~h}$ after larval feeding, leaves of Mp708 treated with 1-MCP exhibited more leaf damage than controls $(P<0.0001$; Fig. 1B). There was no significant increase in leaf damage in Tx601 at any of the feeding times $(P=$ 0.0603; Fig. 1D). The results obtained with Mp708 suggested that blocking ethylene synthesis or perception increased plant susceptibility to FAW feeding. However, the same treatments did not significantly alter the response to insect feeding in Tx601, except for the AVG and $\mathrm{CoCl}_{2}$ treatments at $24 \mathrm{~h}$.

In addition to using leaf damage as a measure of susceptibility, the effect of treated plants on larval growth was also analyzed. RGR instead of the final weight was used to measure insect performance, because it takes into account the variability in the initial larval weights. The RGR of larvae that fed on Mp708 leaves treated with AVG, $\mathrm{CoCl}_{2}$, and 1-MCP were significantly higher than those of larvae reared on control plants for 8, 24, and $48 \mathrm{~h}(P<0.0001$; Fig. 2A and B). In Tx601 there were no significant differences in larval growth rate (RGR) when larvae were reared on plants pretreated with AVG or $\mathrm{CoCl}_{2}(P=0.2709$; Fig. 2C) or $1-\mathrm{MCP}(P=0.7747$; (Fig. 2D).

Because it is possible that the AVG and $\mathrm{CoCl}_{2}$ taken up by the plant could alter insect growth directly, their effect on insect growth in an artificial diet at the same concentrations used for plant treatments was tested. When FAW larvae were reared on artificial diet containing $\mathrm{AVG}$ and $\mathrm{CoCl}_{2}$ for $48 \mathrm{~h}$, there were no significant differences in RGR between larvae reared on diets containing the ethylene synthesis inhibitors and the control $(P=0.8113$; Fig. 3$)$. This indicates that the differences in larval growth rate observed in Mp708 treated with AVG and $\mathrm{CoCl}_{2}$ were not due to the chemicals but to physiological changes within the plant. The results from Figures 1 and 2 indicate that blocking ethylene synthesis and perception in the re- 
sistant maize genotype Mp708 impairs its resistance, because both leaf damage and larval performance increased when the plants were treated. Ethylene biosynthesis and perception are required for resistance signaling in resistant Mp708. However, in the susceptible genotype Tx601, blocking ethylene synthesis or perception appeared to have little or no effect on susceptibility except at $24 \mathrm{~h}$, when leaf damage was slightly higher in plants pretreated with ethylene synthesis inhibitors.

\section{Reduced accumulation of Mir1-CP protein in insect-damaged maize leaves treated with ethylene inhibitors.}

Because previous work (Pechan et al. 2000) demonstrated that the unique defense cysteine proteinase Mir1-CP rapidly accumulated in the whorls of resistant plants in response to FAW herbivory, the following experiments were conducted to determine if blocking ethylene synthesis or perception inhibited the accumulation of Mir1-CP. If Mir1-CP is a defense agent, blocking its accumulation should render the plants susceptible to FAW feeding. Immunoblot analyses were conducted using the tissues collected from treated and control plants from the experiments described in Figures 1 and 2 that were fed on by FAW for $0,8,24$, and $48 \mathrm{~h}$. In Mp708, Mir1-CP was not detected in control plants or plants treated with $\mathrm{AVG}$ or $\mathrm{CoCl}_{2}$ at $0 \mathrm{~h}$, but its abundance increased in control plants as feeding progressed from 8 to $48 \mathrm{~h}$ (Fig. 4A). Although Mir1-CP was present in AVG- and $\mathrm{CoCl}_{2}$-pretreated plants after 8,24 , and $48 \mathrm{~h}$ of larval feeding, the amount that accumulated was considerably less than the control. Inhibiting ethylene perception by 1-MCP also reduced Mir1-CP accumulation after 8,24 , and $48 \mathrm{~h}$ of larval feeding, relative to the control plants (Fig. 4B). As previously demonstrated (Pechan et al. 2000), Mir1-CP did not accumulate in Tx601 under any condition (data not shown). Overall, our results indicated that ethylene inhibitors, whether of biosynthesis or perception, reduced Mir1-CP accumulation and suggested that both ethylene signaling and herbivory are required for accumulation of Mir1-CP in Mp708.

\section{Inhibition of ethylene biosynthesis and perception reduces} but does not prevent insect-induced mirl gene expression.

To determine if mirl RNA and protein levels were correlated, tissues from the same samples used for immunoblot analyses were used to determine the relative abundance of mirl RNA using reverse transcriptase-polymerase chain reac-

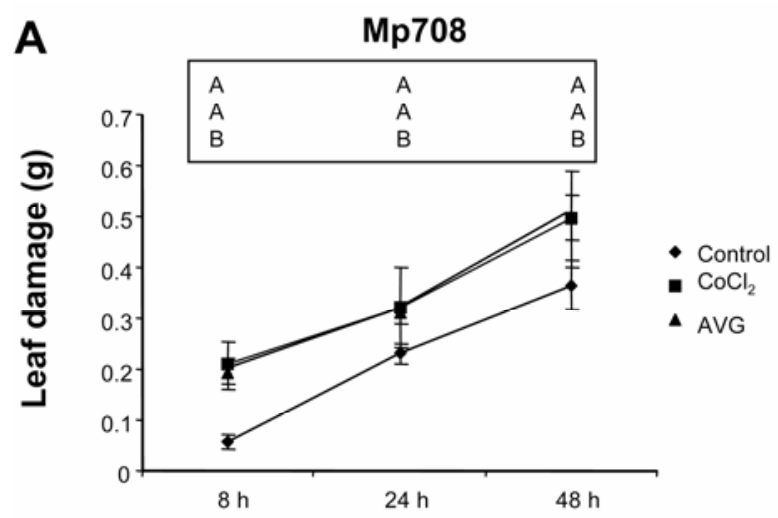

Hours after larval feeding

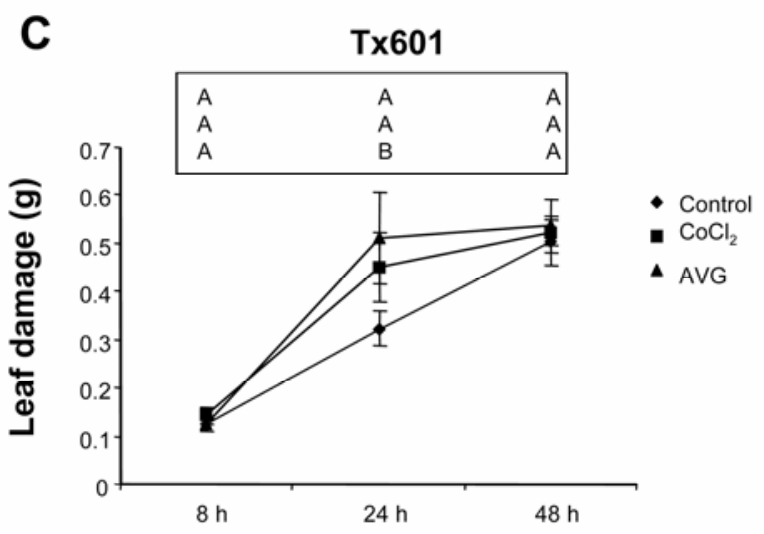

Hours after larval feeding

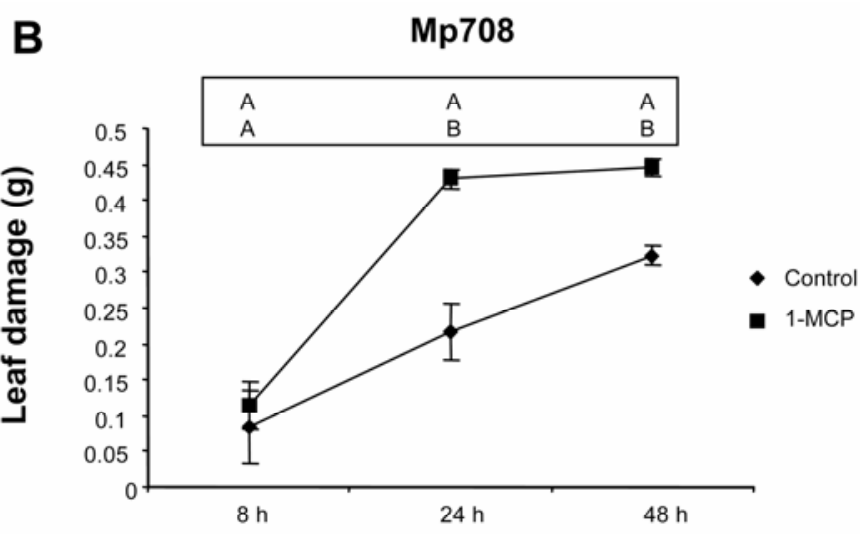

Hours after larval feeding

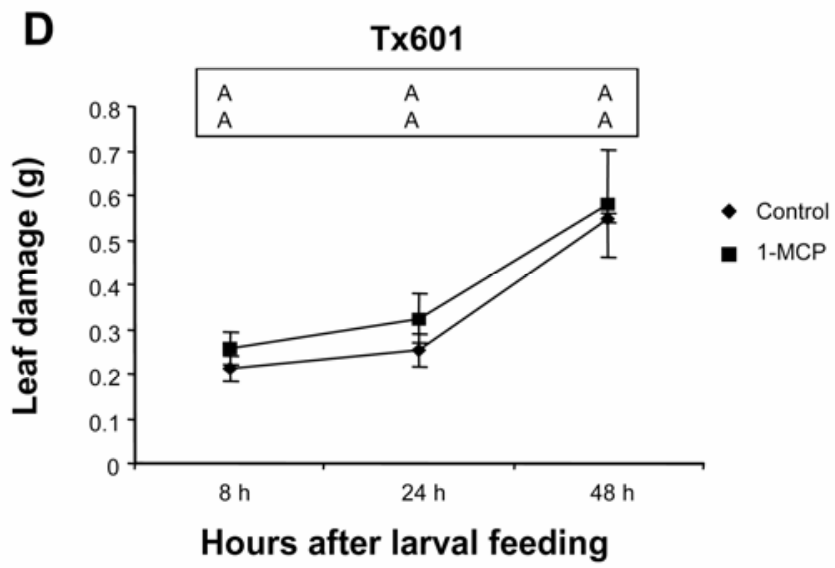

Fig. 1. Ethylene inhibitors increase leaf damage caused by insects in maize leaves. A, Whorls of resistant Mp708 genotype were cut at their base and were fed through cut stems in water solution (Control) or in water supplemented with aminoethoxyvinylglycine (AVG) $(200 \mu \mathrm{M})$ or cobalt chloride $\left(\mathrm{CoCl}_{2}\right)(200$ $\mu \mathrm{M})$, for $24 \mathrm{~h}$. B, Whorls of resistant Mp708 genotype were placed in a sealed Plexiglas chamber, and methylcyclopropane (1-MCP) $(5 \mathrm{mg} /$ liter) was applied as a gas. Control plants were enclosed in Plexiglas chambers without 1-MCP. C, Whorls of susceptible Tx601 genotype were cut at their base and were fed through cut stems in water solution (Control) or in water supplemented with AVG $(200 \mu \mathrm{M})$ or with $\mathrm{CoCl}_{2}(200 \mu \mathrm{M})$ for $24 \mathrm{~h}$. D, Whorls of susceptible Tx601 genotype were placed in Plexiglas chamber, and 1-MCP $(5 \mathrm{mg} / \mathrm{l})$ was applied as a gas. Control plants were enclosed in Plexiglas chambers without 1MCP. Following the 24-h chemical treatment, yellow-green leaf sections were excised, placed in petri plates, and infested with fall armyworm larvae. Larvae were reared on leaves for $0,8,24$, and $48 \mathrm{~h}$. Leaf damage was assessed by taking the difference between initial and final weight of the leaves after each timepoint of larval feeding. The effects of $\mathrm{CoCl}_{2}, \mathrm{AVG}$, and 1-MCP are expressed as leaf damage (means \pm standard error). Different letters indicate significant difference $(P<0.05)$ between treatments at each timepoint according to Tukey's multiple range test. 
tion (RT-PCR). RT-PCR experiments revealed that mirl transcript began to appear after $8 \mathrm{~h}$ of larval feeding and continued to increase over the next 24 to $48 \mathrm{~h}$ (Fig. 5A and B) in Mp708. The mirl transcript was not detected in treated or untreated leaves prior to insect feeding (data not shown). However, in the presence of inhibitors, mirl transcript accumulation in response to larval feeding was less than in controls. Consistent with the results of Mir1-CP protein accumulation, the ACS inhibitor AVG and ACO inhibitor $\mathrm{CoCl}_{2}$ resulted in lower levels of mirl transcripts as compared with untreated controls (Fig. 5A). No accumulation of mirl transcripts in response to larval feeding was detected in treated or control Tx601 (Fig. $5 \mathrm{~A}$ and $\mathrm{B}$ ).

The ethylene antagonist 1-MCP also decreased mirl transcript expression in response to larval feeding in Mp708 after 8, 24, and $48 \mathrm{~h}$. Accumulation of mirl transcripts in Tx601 was not detected in any of the treatments (Fig. 5B). The lower levels of mirl RNA in response to both ethylene biosynthesis and perception inhibitors suggests that ethylene plays a role in regulating the accumulation of mirl in response to herbivory.

Quantitative RT-PCR was used to more accurately assess the effect of herbivory on mirl mRNA levels in Mp708 pretreated with $\mathrm{AVG}, \mathrm{CoCl}_{2}$, and 1-MCP. RNA was extracted from the same samples used for immunoblot and RT-PCR analyses. Because no mirl mRNA was detected in Tx601, these experiments focused on measuring its relative abundance in Mp708. The abundance of the mirl transcript at each timepoint was normalized to that of $18 S \mathrm{rRNA}$. A calibrator sample at timepoint $24 \mathrm{~h}$ of larval feeding was then used to normalize the data. When ethylene biosynthesis enzymes were inhibited by feeding plants with $\mathrm{AVG}$ and $\mathrm{CoCl}_{2}$ (Fig. 6A), ratios of mirl/18S rRNA showed that the mirl gene was induced in response to insect feeding. mirl transcript levels increased approximately twofold between 8 and $24 \mathrm{~h}$ of larval feeding and remained stable at $48 \mathrm{~h}$. When plants were pretreated with 1MCP in sealed plexiglass chambers, a 1.5-fold induction was obtained between 8 and $24 \mathrm{~h}$ of larval feeding and a 4.5 -fold induction was reached after $48 \mathrm{~h}$. This may be due to ethylene accumulation in the sealed chamber in response to larval feeding or the formation of new ethylene receptors that allowed the cells to regain sensitivity to ethylene (Fig. 6B). As expected, a comparison between ethylene inhibitor-treated and untreated controls revealed that $\mathrm{CoCl}_{2}$ reduced mirl transcript levels approximately twofold relative to the control at each timepoint (Fig. 6A). When Mp708 plants were pretreated with AVG prior to insect feeding, mirl transcript levels decreased approxi-
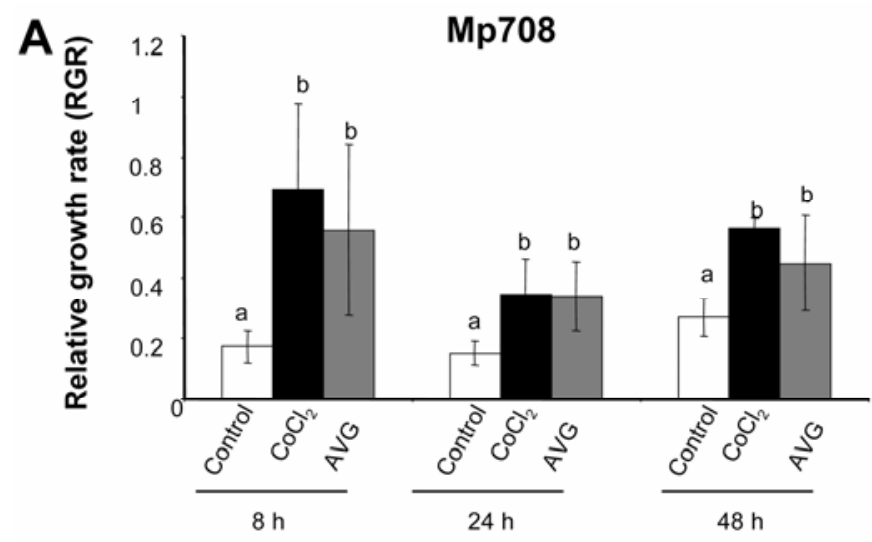

Hours after larval feeding

C

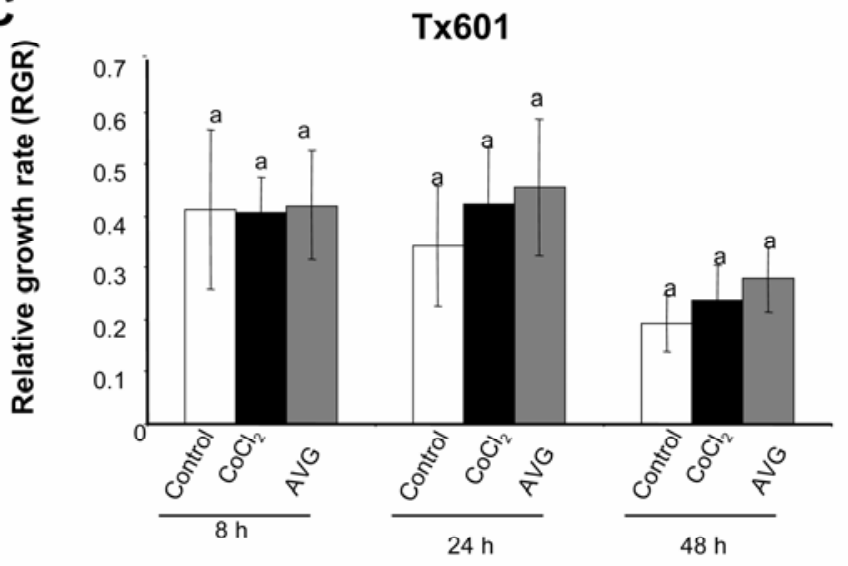

Hours after larval feeding
B

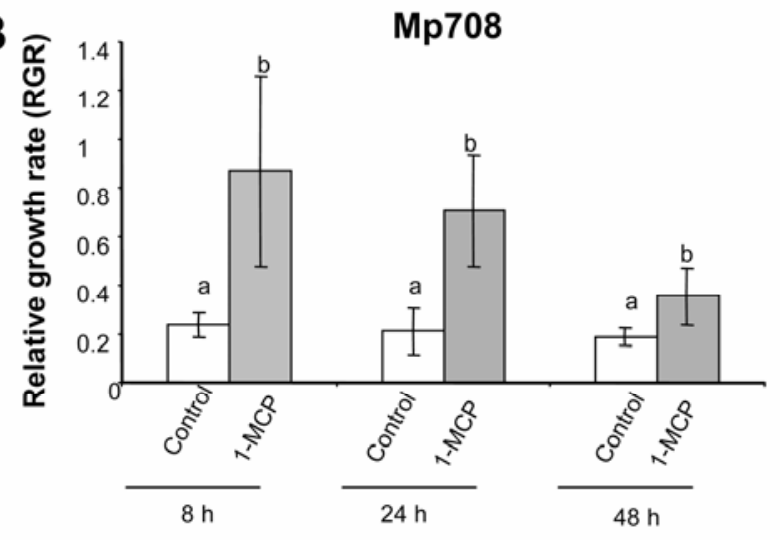

Hours after larval feeding

D

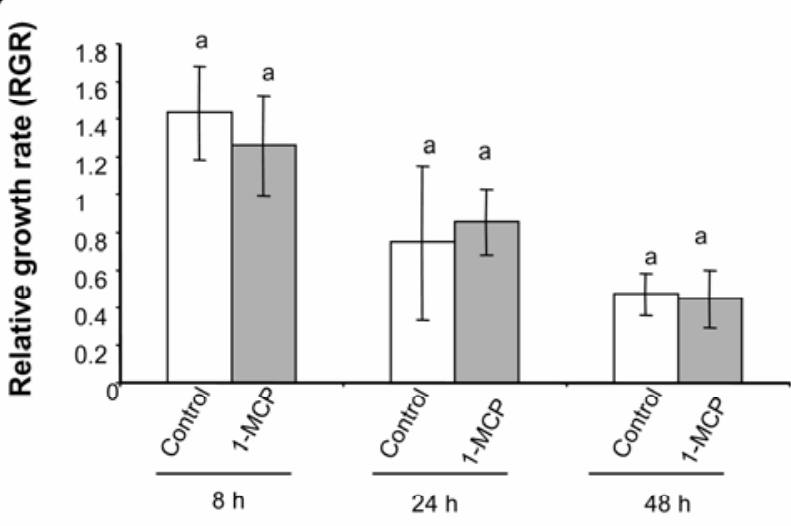

Hours after larval feeding

Fig. 2. Ethylene inhibitors influence larval performance during plant-insect interactions in maize. A, The relative growth rate (RGR) of fall armyworm (FAW) larvae was tested on resistant $\mathrm{Mp} 708$ untreated control and cobalt chloride $\left(\mathrm{CoCl}_{2}\right)$ - and aminoethoxyvinylglycine (AVG)-treated plants. B, The RGR of FAW larvae was tested on resistant Mp708 untreated control and methylcyclopropane (1-MCP)-treated plants. C, The RGR of FAW larvae was tested on susceptible Tx601 untreated control and $\mathrm{CoCl}_{2}$ - and AVG-treated plants. D, The RGR of FAW larvae was tested on susceptible Tx601 untreated control and 1-MCP-treated plants. Third instar larvae were placed simultaneously on whorl sections of each treatment. Larvae were weighed after $0,8,24$, and $48 \mathrm{~h}$ of feeding. Larval performance was measured by the RGR (means \pm standard error). Columns with different letters are significantly $(P<0.05)$ different according to Tukey's multiple range test. 
mately threefold in the treated plants compared with the control at $8 \mathrm{~h}$ and approximately fivefold at 24 and $48 \mathrm{~h}$ (Fig. 6A). Blocking ethylene perception with 1-MCP also reduced mirl transcript levels approximately threefold when compared with the control at each timepoint (Fig. 6B). None of the treatments completely inhibited mirl expression.

\section{DISCUSSION}

\section{Ethylene mediates the insect defense response of Mp708 maize inbred.}

Ethylene has profound effects on plant growth, development, and defense against biotic and abiotic stresses. There are numerous responses to ethylene throughout plant defense, including accumulation of hydrogen peroxide (Moeder et al. 2002) and defense-related genes (Gu et al. 2000; Knoester et al. 1999; Stotz et al. 2000; Thomma et al. 1999). Attack by pathogens or insects or mechanical wounding can induce ethylene production (Argandona et al. 2001; Kahl et al. 2000; Kende 1993; Krupnick et al. 2000; Watanabe et al. 2001). In some cases, stress-induced ethylene leads to defense responses (Abeles et al. 1992); in other cases however, ethylene suppresses herbivore defense responses (Kahl et al. 2001; Winz and Baldwin 2000).

If ethylene plays a crucial role in plant defense mechanisms, one would predict that treatment of plants with exogenous ethylene would enhance resistance to subsequent challenge with insects and pathogens or, conversely, that treatment with ethylene inhibitors would adversely affect their resistance level. This has been demonstrated for a number of plant-insect and plant-pathogen interactions in the eudicots but not in maize (Campbell et al. 2003; Dong et al. 2004; El-Kazzaz et al. 1983; Esquerré-Tugayé et al. 1979; Hudgins and Franceschi 2004; Marte et al. 1993; Thomma et al. 1999). This study was conducted to test the hypothesis that ethylene is a component in the signal transduction pathway leading to Mir1-CP accumulation in the maize inbred Mp708 that is resistant to insect herbivory. Because ethyleneresponse mutants were not available, pharmacological methods were used to inhibit the synthesis and perception of the hormone. The effects of three inhibitors, each blocking different steps in ethylene synthesis and perception, on plant resistance, larval growth, mirlmRNA, and Mir1-CP protein levels were then evaluated. Treating plants with the ACS inhibitor AVG or the ACO inhibitor $\mathrm{CoCl}_{2}$ increased the amount of feeding damage on the whorl tissue and increased the RGR of larvae reared on treated tissues. The treatments reduced but did not completely inhibit insect-induced accumulation of Mir1-CP and mirl. Likewise, inhibiting ethylene perception with 1-MCP had similar effects on herbivory, larval growth, and the accumulation of Mir1-CP and mirl transcripts. Taken together, it appears that, in the insect-resistant maize genotype Mp708, both ethylene synthesis and perception are required for the processes that result in insect defense. It does not appear to be the case for the susceptible genotype Tx601, and we do not know if it is true for all maize lines.

To determine if conserved promoter sequence elements capable of mediating the ethylene-responsive expression of mirl were present, the $5^{\prime}$ region of the mirl promoter sequence (3,197 bp) was examined, using PlantCARE software (Lescot et al. 2002). This analysis identified two GCC boxes (GCCGCC) and two ethylene motifs (ATTTCAAA) in the upstream region of the gene. Ethylene-responsive elements are commonly found in the promoter region of the ethylene-inducible defense genes. Previous studies by Ohme-Takagi and associates (2000) indicated that the ethylene response element binding proteins respond to extracellular signals and interact with the GCC box to modulate ethylene-responsive gene ex- pression. In another study, transcriptome analysis suggested that the ethylene response factor 1 was important in the regulation of ethylene- and jasmonate-dependent defense responses (Lorenzo et al. 2003). Further experimental evidence will be required to establish definite links between these putative promoter elements and their one or more roles in the regulation of mirl expression in response to an ethylene signal.

Although ethylene is a signal in insect-plant defense, it is still not known if it acts directly or in combination with other signaling molecules. Previous studies have demonstrated a link between jasmonate and ethylene in the induction or suppression of defense-related genes (Lorenzo and Solano 2005). In conifers, the methyl-jasmonate (MJ)-induced resistance response to stem pests was tied to increased ethylene production (Hudgins and Franseschi 2004). The same study indicated that JA strongly induced ethylene production in stems, which activated polyphenolic parenchyma (PP) cells, resulting in the production of defensive phenolic compounds. In this case, the ethylene response inhibitor 1-MCP also significantly reduced JA-induced PP cell activation.

It is possible that one or more additional signaling pathways interact with ethylene to regulate the insect defense response in Mp708, because inhibiting ethylene synthesis and perception did not completely eliminate mirl gene and Mir1-CP expression. This may be due to residual amounts of ethylene that were sufficient to trigger the induction of mirl and Mir1-CP. In the case of 1-MCP treatment, it is possible that residual mirl transcript and Mir1-CP accumulation could be due to the synthesis of new ethylene receptors that might resensitize the plant to ethylene (Schaller and Kieber 2002).

Ethylene production is also stimulated by wounding, herbivore and pathogen attack, and other biotic or abiotic stresses (Wang et al. 2002). JA has been reported to stimulate ethylene production in many plants, such as tomato, Arabidopsis, and tobacco (Xu et al. 1994; O'Donnell et al. 1996; Pennincks et al. 1998). It is believed that crosstalk between ethylene and JA pathways enables plants to optimize their defense strategies more efficiently and economically (Baldwin 1998). Two pieces of preliminary data lead us to speculate that JA and ethylene may interact to regulate mirl and Mir1-CP accumulation in re-

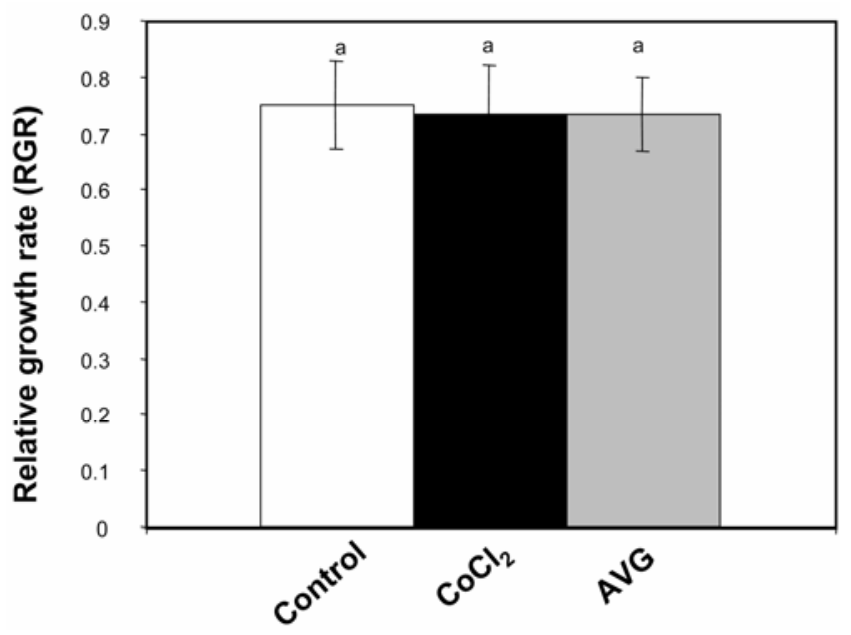

Fig. 3. Inhibitors of ethylene biosynthesis do not affect larval growth on artificial diet. One larva per cup was allowed to feed for $48 \mathrm{~h}$. Single cups with artificial food supplemented with or without cobalt chloride $\left(\mathrm{CoCl}_{2}\right)$ $(200 \mu \mathrm{M})$ and aminoethoxyvinylglycine (AVG) $(200 \mu \mathrm{M})$ were randomly assigned positions in 48-well trays. Larval weight was measured at time zero and, after $48 \mathrm{~h}$ of larval feeding. relative growth rate (RGR) was assessed. The effects of $\mathrm{CoCl}_{2}$ and AVG were expressed as the RGR of larvae (means \pm standard error). Columns with the same letter are not significantly $(P<0.05)$ different according to Tukey's multiple range test. 
sponse to herbivory in Mp708. First, blocking the octadecanoid pathway with $1 \mathrm{mM}$ ibuprofen renders the plant more susceptible to caterpillar feeding (A. L. Harfouche and D. S. Luthe, unpublished data), suggesting that it is also needed to elicit the defense response. Second, measurement of JA levels in uninfested Mp708 plants indicated that they were approximately fivefold higher than those of Tx601 (R. Shivaji, J. Engelberth, and D. S. Luthe, unpublished data). If JA levels are constitutively higher in Mp708, this may result in higher endogenous ethylene levels in the plant, which would explain why treatment with exogenous ethylene did not increase resistance or Mir1-CP expression in Mp708. By blocking the ethylene pathway with inhibitors, we may suppress a constitutively expressed signaling pathway. If endogenous JA and ethylene levels are higher in Mp708, the plant may be ready to respond to caterpillar attack and rapidly accumulate Mir1-CP and other components of its defensive system in response to herbivory. Mp708 plants are small-statured and poor-yielding, which suggests that their insect-defense pathway is always "on," thereby limiting productivity. In some respects, the Mp708 phenotype is similar to that of the Arabidopsis cev1 mutant that has constitutively high production of JA and ethylene (Ellis et al. 2002).

The results of this study, which implicate ethylene in the regulation of mirl gene expression in $\mathrm{Mp708}$, are in agreement with those of O'Donnell and associates (1996), who showed that ethylene and JA are required in the transduction pathway leading from wounding to regulate proteinase inhibitor (pin) gene expression in tomato. The results contrast with those in N. attenuata (Kahl et al. 2000; Winz and Baldwin 2001), in which herbivore-induced ethylene suppressed a direct defense in tobacco and made it more susceptible to herbivory. Currently, we do not know if or how JA and ethylene interact to regulate mirl gene expression in Mp708. It is possible that ethylene is downstream from JA or that the two pathways function in parallel. It will be interesting to determine how ethylene and JA influence each other in response to herbivory in Mp708 and other maize genotypes. Thus a more complete picture of interaction between JA and ethylene in insect defense response in maize awaits the analysis of JA signaling.

A

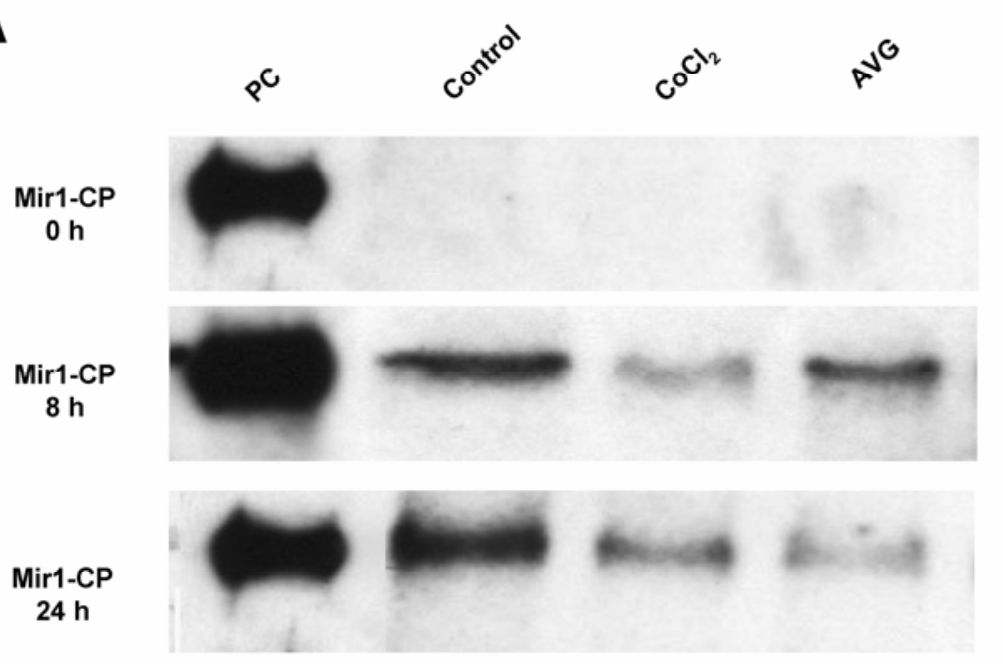

Mir1-CP

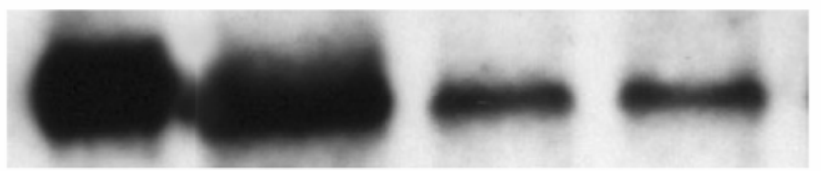

$48 \mathrm{~h}$

B

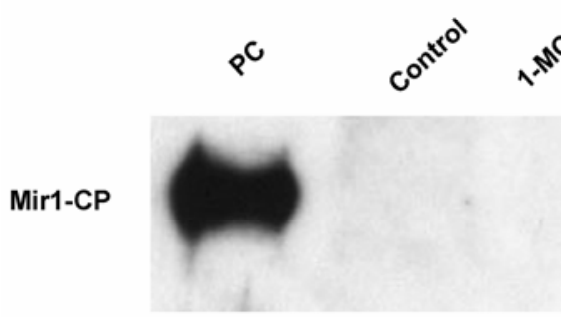

$8 \mathrm{~h}$

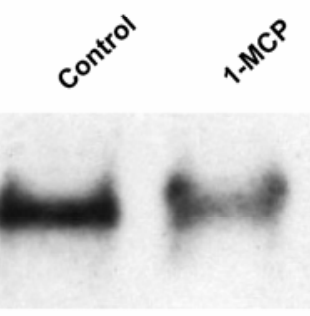

$24 \mathrm{~h}$

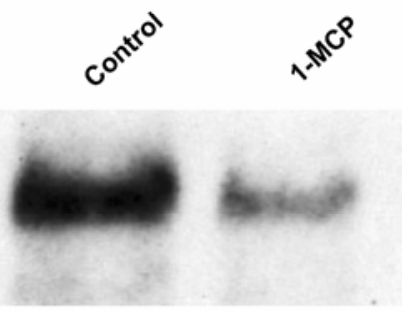

$48 \mathrm{~h}$

Fig. 4. Ethylene inhibitors reduced the accumulation of Mir1-CP protein induced by insect attack in maize. A, Western blot analysis of Mir1-CP protein expression in leaves that were excised from resistant Mp708 plants treated with cobalt chloride and aminoethoxyvinylglycine or untreated controls. B, Western blot analysis of Mir1-CP protein expression in leaves that were excised from resistant Mp708 plants treated with methylcyclopropane or untreated controls. Total proteins were extracted after $0,8,24$, and $48 \mathrm{~h}$ of larval feeding and were subjected to sodium dodecyl sulfate-polyacrylamide gel electrophoresis (15 $\mu \mathrm{g}$ of protein per lane). Blots were treated with monoclonal antibodies against Mir1-CP and followed by a secondary incubation using goat anti-mouse horseradish peroxidase-conjugated serum. The signal was detected using SuperSignal west femto maximum sensitivity substrate. The positive control (PC) was a protein extract from Mp708 callus. 


\section{MATERIALS AND METHODS}

Plant growth and FAW rearing.

Maize (Zea mays L.) genotypes used in this study were the resistant inbred Mp708 (Williams et al. 1990) and the susceptible inbred Tx601 (Williams et al. 1989). Plants were grown under greenhouse conditions at the Plant Science Research Center, Mississippi Agricultural and Forestry Experiment Station (Mississippi State University) until they were four to five weeks old and in the mid-whorl (V8) developmental stage (Ritchie et al. 1986). FAW were reared on artificial diet (Davis 1989) at the U.S. Department of Agriculture-Agricultural Research Service, Corn Host Plant Research Unit, Insect-Rearing
Laboratory. Unless otherwise noted, larvae used for infestations were 5 days posthatch or approximately third instar.

\section{Ethylene response inhibitor treatments.}

$\mathrm{CoCl}_{2}$ and AVG were purchased from Sigma-Aldrich (St. Louis). 1-MCP commercially named EthylBloc (0.43\% [wt/wt] 1-MCP) was purchased from Floralife (Walterboro, SC, U.S.A.). Plants were taken to the laboratory, cut at the base of their stems, and stem-fed in a solution containing 200 $\mu \mathrm{M}$ AVG or $200 \mu \mathrm{M} \mathrm{CoCl}_{2}$ for a period of $24 \mathrm{~h}$. The concentration of $200 \mu \mathrm{M}$ was selected because it gave the maximum inhibition of Mir1-CP accumulation in pilot dose-response experiments. Untreated controls were placed in water and sub-

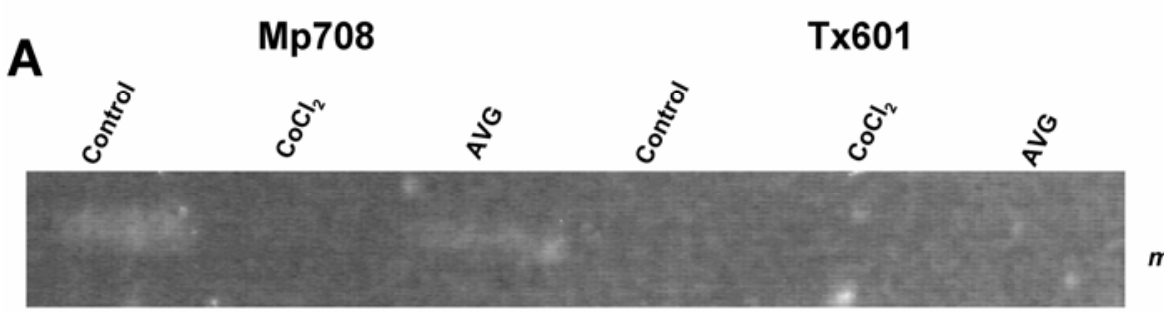

mir1

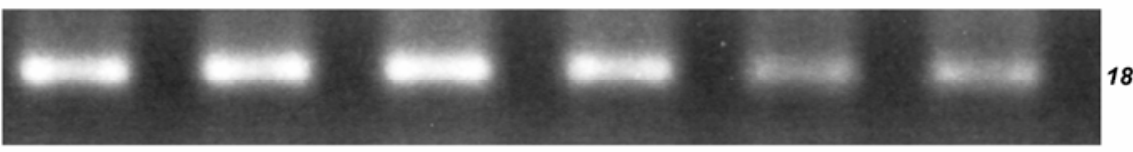

$8 \mathrm{~h}$

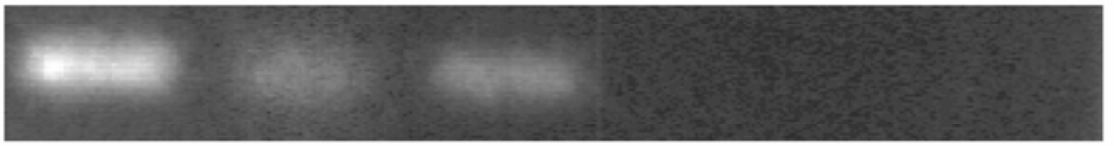

mir1

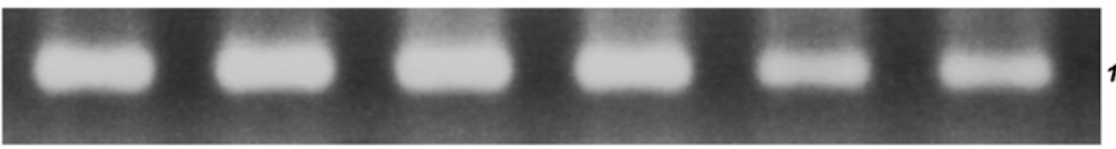

18S rRNA

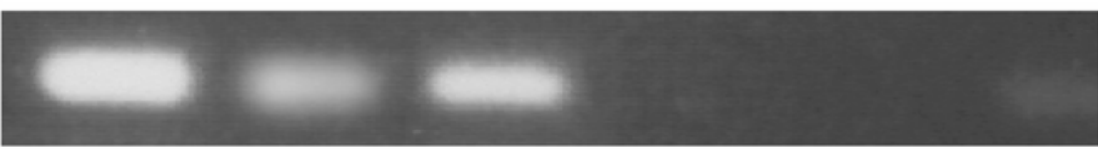

mir1

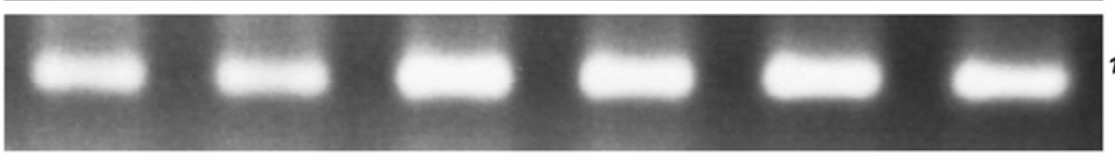

18 S rRNA

B

Tx601

Mp708
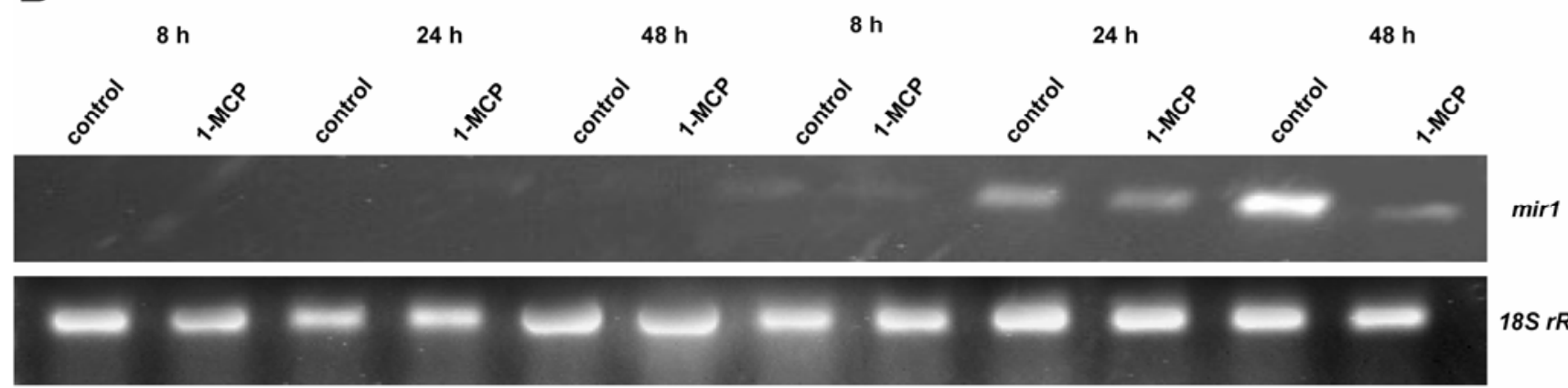

18 S rRNA

Fig. 5. Inhibiting ethylene biosynthesis and perception decreases mirl mRNA expression in plant-insect defense response in maize. A, Effects of inhibitors of ethylene biosynthesis on mirl gene expression were analyzed by reverse transcriptase-polymerase chain reaction (RT-PCR) experiments. First-strand cDNA synthesis was prepared from total RNA extracted from a leaf segment approximately $1 \mathrm{~cm}$ distal from the site of insect damage from leaves collected after 0, 8, 24, and $48 \mathrm{~h}$ of larval feeding. Samples were taken from Mp708 and Tx601 plants that were untreated controls or cobalt chloride- and aminoethoxyvinylglycine-treated and were challenged with fall armyworm (FAW) larvae in petri plates. $18 S$ rRNA was used as a constitutively expressed control. B, Effects of an inhibitor of ethylene perception on mirl gene expression were analyzed by RT-PCR experiments. First-strand cDNA synthesis was prepared from total RNA extracted from a leaf segment approximately $1 \mathrm{~cm}$ distal from the site of insect damage from leaves collected after $0,8,24$, and 48 $\mathrm{h}$ of larval feeding. Leaves were excised from Mp708 and Tx601 plants treated with methylcyclopropane (1-MCP) and challenged with FAW larvae in petri plates. Control plants were enclosed in Plexiglas chambers without 1-MCP. 18S rRNA was used as a constitutively expressed control. 
jected to the same conditions but without inhibitors. To block ethylene perception, maize plants were placed in sealed 11-liter Plexiglas chambers, and 1-MCP gas was generated by dissolving $450 \mathrm{mg}$ of EthylBloc powder containing $0.14 \% 1-\mathrm{MCP}$ in $9 \mathrm{ml}$ of EthylBloc releasing buffer in a glass beaker placed inside the sealed Plexiglas chamber. This resulted in a 1-MCP concentration of $5 \mathrm{mg} / \mathrm{l}$, which is approximately 10-fold greater than the recommended dosage. Control plants were subjected to the same conditions, but only the releasing buffer was present. In preliminary experiments, plants were sprayed with ethephon at concentrations of 1,10 , and $50 \mathrm{mM}$ (Laudert et al. 1998) or were treated with a ripening banana (Chao et al. 1999 ) in the same Plexiglas chambers described above.

\section{A}
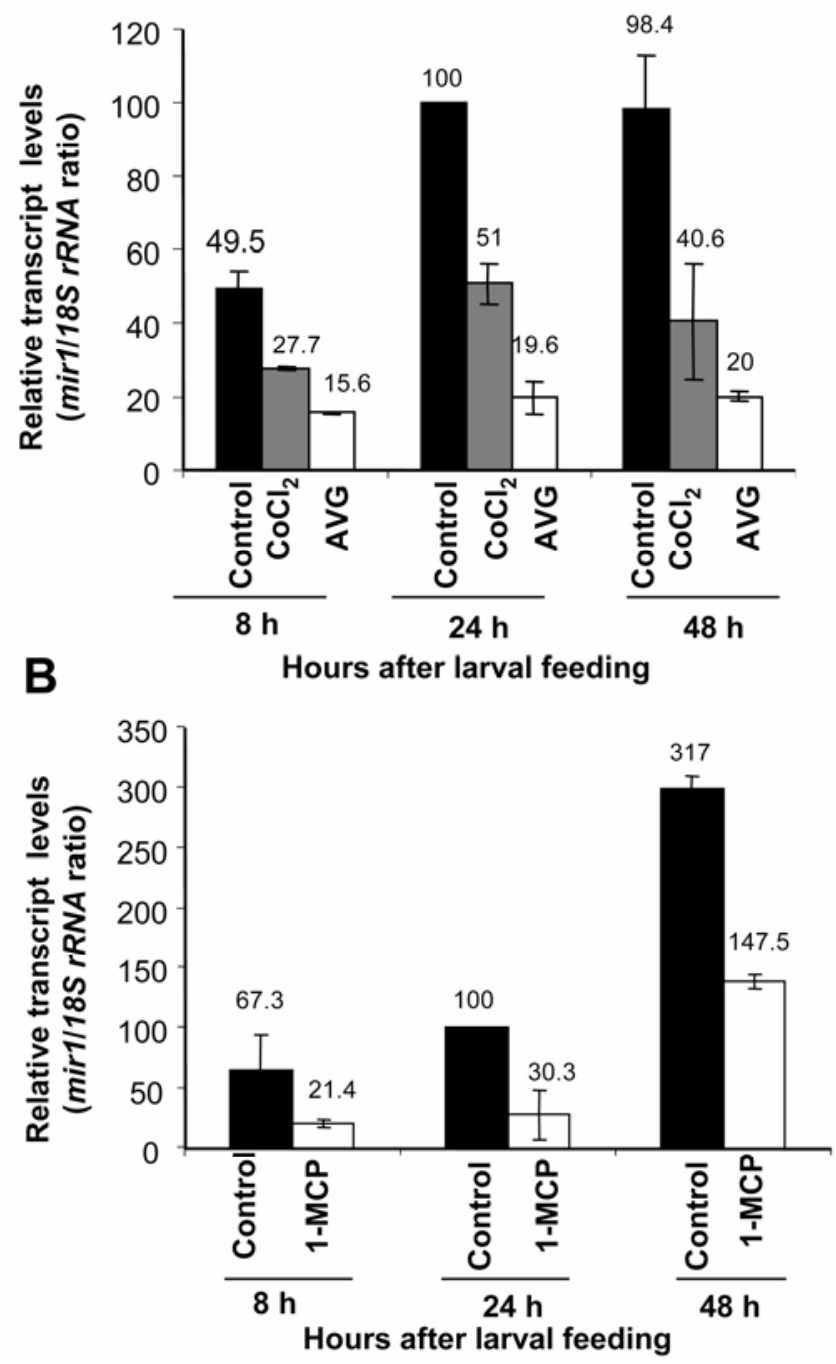

Fig. 6. Inhibitors of ethylene biosynthesis and perception decrease insectresponsive defense gene expression in maize. A, Analysis of mirl transcript level in untreated control and cobalt chloride- and aminoethoxyvinylglycine-treated Mp708 plants after 8, 24, and $48 \mathrm{~h}$ of larval feeding by real-time quantitative PCR (RT-Q-PCR). B, Analysis of mirl transcript level in untreated control and methylcyclopropane-treated Mp708 plants. Total RNA was isolated from leaves at each timepoint of larval feeding, was converted to cDNA, and was used as a template in RT-Q-PCR assays. mirl transcript levels were normalized to the expression of $18 S \mathrm{rRNA}$ (multiplied by 100 for clarity), which appeared to be constant in our conditions. $18 \mathrm{~S} r R N A$ reference gene was used as an external control. Average data with error bars from two independent experiments $(n=4)$ are presented. The numbers on each bar show transcript levels of mirl gene relative to the $18 S$ rRNA transcript levels.

\section{Insect infestation.}

Following the 24-h inhibitor treatment, yellow-green leaf sections (approximately $4 \mathrm{~cm}$ wide) were excised and weighed at time zero and after each timepoint of larval feeding. Eight Leaf sections (eight per petri plate) were placed on a layer of moistened filter paper and were infested with FAW larvae (five per plate). The first set of treatments consisted of water, $\mathrm{CoCl}_{2}$, and AVG. The second set of treatments consisted of the buffer control and 1-MCP. A single experiment consisted of the first and the second set of treatments. Each experiment (biological replicate) was conducted twice. In the first experiment, there were two petri plates (two replicates) per treatment. In the second experiment there were four petri plates (four replicates) per treatment.

Larval growth, leaf damage assays, and harvest of plants.

Larval growth was measured as RGR under the following conditions: $\mathrm{RGR}=$ final weight - initial weight/(average weight/number of days) (Waldbauer 1968). Leaf damage was measured as the weight difference between time zero and the other timepoint. Data were analyzed using the general linear model procedure of the SAS Institute (Cary, NC, U.S.A.). When indicated, Tukey's multiple range test was used to test for differences among treatment means (at $P=0.05$ ). Tissues $(1 \mathrm{~cm}$ of leaf tissue immediately adjacent to the wounding site caused by insect feeding) from leaves subjected to the three types of ethylene inhibitors and controls were harvested at 0 , 8,24 , and $48 \mathrm{~h}$ following larval feeding, were immediately placed in liquid nitrogen, and were stored at $-80^{\circ} \mathrm{C}$ for protein and RNA gene expression analyses.

\section{FAW feeding on artificial diet.}

For bioassays, FAW larvae were placed in 30-ml plastic insect diet cups (Bio-Serv, Frenchtown, NJ, U.S.A.). Each cup contained artificial diet (Davis 1989) supplemented with or without $\mathrm{CoCl}_{2}(200 \mu \mathrm{M})$ and AVG $(200 \mu \mathrm{M})$. Cups were randomly assigned positions in 48-well trays. Each cup contained one larva and feeding was for $48 \mathrm{~h}$. The general linear model procedure of the SAS Institute under replicated and randomized conditions was used for statistical analyses. When indicated, Tukey's multiple range test was used to test for differences among treatment means (at $P=0.05$ ). Each treatment was replicated 16 times, and the experiment was repeated twice.

\section{Protein extraction and expression analysis.}

Protein extracts were prepared from insect-damaged leaf tissues of untreated controls or treated plants with ethylene inhibitors. Frozen samples $(200 \mathrm{mg})$ were ground to a powder in liquid $\mathrm{N}_{2}$ using a mortar and pestle. Just as the liquid $\mathrm{N}_{2}$ evaporated, $0.4 \mathrm{ml}$ of sodium dodecyl sulfate (SDS) sample buffer (Laemmli 1970) was added and the tissues were further ground. After thawing, the homogenates were heated at $95^{\circ} \mathrm{C}$ for $5 \mathrm{~min}$ and then were briefly centrifuged at $12,000 \times \mathrm{g}$ to pellet the cellular debris. The resulting supernatant was stored at $-20^{\circ} \mathrm{C}$ until analyzed. Prior to electrophoresis, sample protein concentrations were measured using a protein quantification assay, RCDC (Bio-Rad Laboratories, Hercules, CA, U.S.A.), with bovine serum albumin as a standard. One-dimensional SDS-polyacrylamide gel electrophoresis (PAGE) was performed using $5 \%(\mathrm{wt} / \mathrm{vol})$ stacking and $12 \%(\mathrm{wt} / \mathrm{vol})$ resolving gel bis-acrylamide concentrations, using the buffer system of Laemmli (1970) in a Mini-Protean II electrophoresis apparatus (Bio-Rad Laboratories), with $15 \mu \mathrm{g}$ of protein loaded per lane. The positive control for immunoblot analyses was protein extracted from Mp708 callus, which has been shown to constitutively overproduce Mir-CP (Jiang et al. 
1995). Constant voltage of $50 \mathrm{~V}$ was applied for $1 \mathrm{~h}$, followed by $150 \mathrm{~V}$ until the tracking dye (bromophenol blue) reached the bottom of the gel. For all immunoblots, a duplicate SDSPAGE gel was run and stained with Coomassie brilliant blue $\mathrm{R}$ 250 to confirm that equal amounts of protein were loaded in each lane. Following SDS-PAGE, immunoblotting of proteins was performed as described previously (Pechan et al. 2000). Immunolabeling of blots was performed using monoclonal antibodies against Mir1-CP, prepared according to Goding (1980), and a secondary hybridization using goat anti-mouse horseradish peroxidase-conjugated serum. Signal was detected using SuperSignal west femto maximum sensitivity substrate (Pierce Biotechnology, Rockford, IL, U.S.A.). Two repetitions were conducted for each treatment, and one representative result is shown.

\section{RNA extraction and expression analysis.}

Total RNA was extracted from $100 \mathrm{mg}$ of treated and untreated leaves using NucleoSpin RNA plant kit (MachereyNagel, Düren, Germany), with a DNase I treatment applied directly onto the silica membrane of the Macherey-Nagel column as outlined by the manufacturer. The RNA samples were quantified spectrophotometrically at $260 \mathrm{~nm}$. The RNA quality was also checked by $1.0 \%$ agarose gel electrophoresis, stained with $0.5 \mu \mathrm{g}$ of ethidium bromide per milliliter. Total RNA (100 ng) was reverse-transcribed using Ready-To-Go RT-PCR beads two-step protocol according to the manufacturer's instructions (Amersham Pharmacia Biotech, Piscataway, NJ, U.S.A.). To each bead reaction was added $100 \mathrm{ng}$ of RNA, 0.5 $\mu \mathrm{g}$ of oligo $\mathrm{dT}_{(12-18)}$ or $2.5 \mu \mathrm{g} \mathrm{p}(\mathrm{dN})_{6} \mathrm{cDNA}$ synthesis primers, $0.5 \mu \mathrm{M}$ of mirl (National Center for Biotechnology Information accession number AF019145) gene-specific primers (mirlF, 5'-CGCGTTCCGGTTCGTCATC-3' and mirlR, 5'CCTCCTAAGCAAGAACC-3'), $4 \mathrm{mM} \mathrm{MgCl}_{2}$, and RT-PCR grade water (Ambion, Austin, TX, U.S.A.) to a final volume of $50 \mu$ l. Primers were designed with Primers Select software (Lasergene; DNASTAR, Madison, WI, U.S.A.) and were synthesized by Invitrogen (Invitrogen Corp. Carlsbad, CA, U.S.A.). For the first step, only oligo $\mathrm{dT}_{(12-18)}$ or $\mathrm{p}(\mathrm{dN})_{6}$ firststrand cDNA synthesis primer was added to the dissolved beads, and reaction was incubated on a heat block at $42^{\circ} \mathrm{C}$ for 30 min when oligo $\mathrm{dT}_{(12-18)}$ was used or at $20^{\circ} \mathrm{C}$ for $10 \mathrm{~min}$ then at $42^{\circ} \mathrm{C}$ for $30 \mathrm{~min}$ when random hexamer was used. Following RT reaction, the mix was incubated in a thermal cycler at $95^{\circ} \mathrm{C}$ for $5 \mathrm{~min}$ to inactivate the reverse transcriptase $(\mathrm{M}$ $\mathrm{MuLV}$ ) and to completely denature the template. In the second step, mirl gene-specific primers were added, and synthesis was performed at $95^{\circ} \mathrm{C}$ for $1 \mathrm{~min}, 55^{\circ} \mathrm{C}$ for $1 \mathrm{~min}$, and $72^{\circ} \mathrm{C}$ for $1 \mathrm{~min}$ for 35 cycles. 18S $r R N A$ forward primer $5^{\prime}$ TCCTGAGTAACGAACGAGACC-3' and reverse primer $5^{\prime}$ CACGATGAAATTTCCCAAGAT-3' were used to amplify $18 S$ rRNA gene, which was used as a housekeeping gene, and amplification was performed at $95^{\circ} \mathrm{C}$ for $1 \mathrm{~min}, 60^{\circ} \mathrm{C}$ for 1 min, and $72^{\circ} \mathrm{C}$ for $1 \mathrm{~min}$ for 35 cycles. PCR reactions were carried out in a Mastercycler gradient (Eppendorf, Hamburg, Germany). To ensure that no false-positive PCR fragments would be generated from genomic DNA contamination or nonspecific DNA amplification, a second aliquot of total RNA was treated similarly, omitting the reverse transcriptase step, and those samples were used as minus reverse transcriptase controls. PCR products were analyzed on a $1.8 \%$ agarose/ ethidium bromide gel run in $1 \times$ tris-borate-EDTA buffer. Two repetitions were conducted for each treatment, and one representative result is shown. PCR products for mirl and $18 \mathrm{~S}$ rRNA genes were cloned into pCR2.1 plasmids using the TA cloning kit (Invitrogen Corp.). The cloned products were sequenced using the ABI Prism Big Dye terminator cycle se- quencing ready reaction kit (Applied Biosystems, Foster City, CA, U.S.A.) and were compared against GenBank, using the BLAST program to confirm identity.

Real-time PCR was performed on a Roche Lightcycler 2.0 instrument. Oligonucleotide primers were synthesized and high-pressure liquid chromatography (HPLC)-purified by Invitrogen. Primer design and optimization concerning primer dimer, self-priming formation, and primer melting temperature was done with LightCycler Probe Design Software, v.1.0 (Roche Applied Science, Mannheim, Germany). Reverse transcription of mRNA was carried out in a $20-\mu$ l final volume from $1 \mu \mathrm{g}$ total RNA, using $10 \mathrm{U}$ Transcriptor reverse transcriptase (Roche) according to the manufacturer's instructions with either $10 \mu \mathrm{M}$ oligo $(\mathrm{dT})_{15}$ or $3.2 \mu \mathrm{g}$ random primer $\mathrm{p}(\mathrm{dN})_{6}$ (Roche). Transcriptor reverse transcriptase was used in combination with $20 \mathrm{U}$ of Protector RNase inhibitor and $1 \mathrm{mM}$ of each PCR nucleotide mix (Roche). PCR was carried out with the LC fast start DNA Master ${ }^{\text {PLUS }}$ SYBR green I kit (Roche), using $2 \mu \mathrm{l}$ of cDNA, corresponding to $100 \mathrm{ng}$ of total RNA in a $20-\mu l$ final volume, and $0.5 \mu \mathrm{M}$ of each HPLC-purified primer for target gene (mirl, maize insect resistance: forward primer, 5'-CTACTGGATCGTGAAGAACTCGTG-3' and reverse primer, 5'-CTCCCTCCTAAGCAAGAACCATC-3') and reference gene (18S rRNA: forward primer, 5'-TCCTGAG TAACGAACGAGACC-3' and reverse primer, 5'-CACGATGA AATTTCCCAAGAT- $3^{\prime}$ ). For each sample, two reactions, one for mirl and one for the reference gene $18 S$ rRNA, were performed in separate capillaries. In the LightCycler 2.0 instrument (Roche), each reaction capillary was incubated for 10 min at $95^{\circ} \mathrm{C}$ before 45 cycles at $95^{\circ} \mathrm{C}$ for $10 \mathrm{~s}$, specific annealing temperature for $5 \mathrm{~s}$, and $72^{\circ} \mathrm{C}$ for $10 \mathrm{~s}$. Finally, amplified products were denatured $\left(95^{\circ} \mathrm{C}\right.$ for $\left.0 \mathrm{~s}\right)$, renatured $\left(65^{\circ} \mathrm{C}\right.$ for 15 s), and progressively denatured $\left(95^{\circ} \mathrm{C}\right.$ for $0 \mathrm{~s}$, step over $0.1^{\circ} \mathrm{C} / \mathrm{s}$ for the melting curve analysis). The PCR run was concluded with a $40^{\circ} \mathrm{C}$ incubation for $30 \mathrm{~s}$. Both primer combinations (mirlBF/mirlBR and $18 S$ rRNAF/18S rRNAR) were tested (fusion curve, linearity, and efficiency of the primers). The primer combinations for mirl and $18 S$ rRNA have a PCR efficiency of $87 \%$. Fluorescence was monitored at the end of the $72^{\circ} \mathrm{C}$ extension step in each cycle, and the second derivative maximum algorithm method was used to calculate crossing points $(\mathrm{Cp})$. $\mathrm{Cp}$ is defined as the point at which the fluorescence rises appreciably above the background fluorescence. Amplification specificity was checked using melting curve following the manufacturer's instructions. A nontemplate control was run for each primer pair to assess the overall specificity and to ensure that primer dimers were not interfering with amplification detection. Melting curve analysis showed a single sharp peak for all samples, and agarose gel electrophoresis showed a single band at the expected size. The calculation method used was based on PCR efficiency-corrected relative quantification normalized to a calibrator. To determine mirl transcript levels, the ratio of mirl to $18 S$ rRNA in an unknown sample relative to the mirl to $18 S$ rRNA ratio in a calibrator sample was determined using LC relative quantification software, v.4.0 (Roche Applied Science). The calibrator is included in each run. Quantification using external standard curves for target and reference genes method was carried out with relative quantification software. Standard curves were achieved from fivefold dilutions of PCR product. Determination of the relative mirl/18S ratio was a function of the PCR reaction efficiency and the $\mathrm{Cp}$ of mirl and $18 S$ rRNA of the unknown and the calibrator sample. To calculate the calibrator normalized relative ratio, the amount of mirl/18S in each sample $\left[\mathrm{N}_{\mathrm{T}(\mathrm{S})} / \mathrm{N}_{\mathrm{R}(\mathrm{S})}\right]$ was divided by the ratio of mir $1 / 18 S$ of the calibrator $\left[\mathrm{N}_{\mathrm{T}(\mathrm{C})} / \mathrm{NR(C)}\right]$. The normalized ratio was then calculated by the formula Normalized Ratio $=\mathrm{E}_{\mathrm{T}}{ }^{\mathrm{CpT}(\mathrm{C})-\mathrm{Cp} T(\mathrm{~S})} \times \mathrm{E}_{\mathrm{R}}{ }_{\mathrm{CPR}(\mathrm{S})-\mathrm{CpR}(\mathrm{C})}$, where $\mathrm{E}_{\mathrm{T}}=$ efficiency 
of the target gene mirl, $\mathrm{E}_{\mathrm{R}}=$ efficiency of the reference gene $18 S, \mathrm{CpT}(\mathrm{C})-\mathrm{CpT}(\mathrm{S})=\mathrm{Cp}$ of target calibrator subtracted from $\mathrm{Cp}$ of target unknown sample, and $\mathrm{CpR}(\mathrm{S})-\mathrm{CpR}(\mathrm{C})=\mathrm{Cp}$ of reference unknown sample subtracted from $\mathrm{Cp}$ of reference calibrator. This formula is in accordance with Roche Applied Science Technical Note No. LC 13/2001. Duplicate RNA extractions or technical replicates were done for each treatment for both experiments, therefore $n=4$. Data were exported to Microsoft Excel for further analysis.

\section{ACKNOWLEDGMENTS}

We thank S. Wolfe and C. Daves for their excellent assistance in insect rearing. This work has been supported by grants from Mississippi State Life Science and Biotechnology Institute and the National Science Foundation (IBN0236150). This is report 10691 of the Mississippi Agricultural and Forestry Experiment Station.

\section{LITERATURE CITED}

Abeles, F. B., Morgan, P. W., and Saltveit, M. E., Jr. 1992. Ethylene in Plant Biology, 2nd ed. Academic Press. San Diego, CA, U.S.A.

Amrhein, N., and Wenker, D. 1979. Novel inhibitors of ethylene production in higher plants. Plant Cell Physiol. 20:1635-1642.

Argandona, V. H., Chaman, M., Cardemil, L., Munoz, O., Zuniga, G. E., and Corcuera, L. J. 2001. Ethylene production and peroxidase activity in aphid-infested barley. J. Chem. Ecol. 27:53-68.

Baldwin, I. T., and Preston, C. A. 1999. The eco-physiological complexity of plant responses to insect herbivores. Planta 208:137-145.

Baldwin, I. T. 1998. Jasmonate-induced responses are costly but benefit plants under attack in native populations. Proc. Natl. Acad. Sci. U.S.A. 95:8113-8118.

Bent, A. F., Innes, R. W., Ecker, J. R., and Staskawicz, B. J. 1992. Disease development in ethylene-insensitive Arabidopsis thaliana infected with virulent and avirulent Pseudomonas and Xanthomonas pathogens. Mol. Plant-Microbe Interact. 5:372-378.

Bleecker, A. B., and Kende, H. 2000. Ethylene: A gaseous signal molecule in plants. Annu. Rev. Cell Dev. Biol. 16:1-18.

Campbell, E. J., Schenk, P. M., Kazan, K., Penninckx, I. A., Anderson, J. P., Maclean, D. J., Cammue, B. P., Ebert, P. R., and Manners, J. M. 2003. Pathogen-responsive expression of a putative ATP-binding cassette transporter gene conferring resistance to the diterpenoid sclareol is regulated by multiple defense signaling pathways in Arabidopsis. Plant Physiol. 133:1272-1284.

Cervantes, E., Rodriguez, A., and Nicolas, G., 1994. Ethylene regulates the expression of a cysteine proteinase gene during germination of chickpea (Cicer arietinum L.). Plant Mol. Biol. 25:207-215.

Chang, C., Kwok, S. F., Bleecker, A. B., and Meyerowitz, E. M. 1993. Arabidopsis ethylene-response gene ETR1: Similarity of product to two-component regulators. Science 262:539-544.

Chao, W. S., Gu, Y. Q., Pautot, V. V., Bray, E. A., and Walling, L. L. 1999. Leucine aminopeptidase RNAs, proteins, and activities increase in response to water deficit, salinity, and the wound signals systemin, methyl jasmonate, and abscisic acid. Plant Physiol. 120: 979-992.

Davis, F. M. 1989. Rearing the southwestern corn borer and fall armyworm at Mississippi State. Pages 27-36 in: Toward Insect Resistant Maize for the Third World: Proceedings of the International Symposium on Methodologies for Developing Host Plant Resistance to Maize Insects. International Maize and Wheat Improvement Center (CIMMYT), El Batan, Mexico.

Dempsey, D. M. A., and Klessig, J. S. 1999. Salicylic acid and disease resistance in plants. Crit. Rev. Plant Sci. 18:547-575.

Dong, H.-P., Peng, J., Bao, Z., Meng, X., Bonasera, M. J, Chen, G., Beer, V.S., and Dong, H. 2004. Downstream divergence of the ethylene signaling pathway for harpin-stimulated Arabidopsis growth and insect defense. Plant Physiol. 136:3628-3638.

Dong, X. 1998. SA, JA, ethylene, and disease resistance in plants. Curr. Opin. Plant Biol. 1:316-323.

Ecker, J., and Davis, R. W. 1987. Plant defense genes are regulated by ethylene. Proc. Natl. Acad. Sci. U.S.A. 84:5202-5206.

El-Kazzaz, M. K., Chordas, A., and Kader, A. A. 1983. Physiological and compositional changes in orange fruit in relation to modification of their susceptibility to Penicillium italicum by ethylene treatments. J. Am. Soc. Hortic. Sci. 108:618-622.

Ellis, C., Karafyllidis, I., Wasternack, C., and Turner, J. G. 2002. The Arabidopsis mutant cev1 links cell wall signaling to jasmonate and ethylene responses. Plant Cell 14:1557-1566.
Esquerré-Tugayé, M. T., Lafitte, C., Mazau, D., Toppan., and Touze, A. 1979. Cell surfaces in plant-microorganism interactions. II. Evidence for the accumulation of hydroxyproline-rich glycoproteins in the cell wall of diseased plants as a defense mechanism. Plant Physiol. 64:320326.

Genoud, T., and Métraux, J. P. 1999. Cross-talk in plant cell signaling: structure and function of the genetic network. Trends Plant Sci. 4:503507.

Goding, J. W. 1980. Antibody production by hybridomas. J. Immunol. Methods 39:285-308.

Gu, Y. Q., Yang, C., Thara, V. K., Zhou, J., and Martin, G. B. 2000. Pti4 is induced by ethylene and salicylic acid, and its product is phosphorylated by the Pto kinase. Plant Cell 12:771-786.

Guo, H., and Ecker, J. R. 2004. The ethylene signaling pathway: New insights. Curr. Opin. Plant Biol. 7:40-49.

Hoffman, T., Schmidt, J. S., Zheng, X., and Bent, A. F. 1999. Isolation of ethylene-insensitive soybean mutants that are altered in pathogen susceptibility and gene-for-gene disease resistance. Plant Physiol. 119:935950.

Hua, J., and Meyerowitz, E. M. 1998. Ethylene responses are negatively regulated by a receptor gene family in Arabidopsis thaliana. Cell 94:261-271.

Hua, J., Chang, C., Sun, Q., and Meyerowitz, E. M. 1995. Ethylene insensitivity conferred by Arabidopsis ERS gene. Science 269:1712-1714.

Hudgins, J. W., and Franceschi, V. R. 2004. Methyl jasmonate-induced ethylene production is responsible for conifer phloem defense responses and reprogramming of stem cambial zone for traumatic resin duct formation. Plant Physiol. 135:2134-2149.

Ishige, F., Mori, H., Yamazaki, K., and Imaseki, H. 1993. Identification of a basic glycoprotein induced by ethylene in primary leaves of azuki bean as a cationic peroxidase. Plant Physiol. 101:193-199.

Jiang, B., Siregar, U., Willeford, K. O., Luthe, D. S., and Williams W. P. 1995. Association of a 33-kilodalton cysteine proteinase found in corn callus with the inhibition of fall armyworm larval growth. Plant Physiol. 108:1631-1640.

Jones, L. M., Larsen, B. P., and Woodson, R. W. 1995. Ethylene-regulated expression of a carnation cysteine proteinase during flower petal senescence. Plant Mol. Biol. 28:505-512.

Kahl, J., Siemens, H. D., Aerts, J. R., Gäbler, R., Kühnemann, F., Preston, A. C., and Baldwin, T. 2000. Herbivore-induced ethylene suppresses a direct defense but not a putative indirect defense against an adapted herbivore. Planta 210:336-342.

Karban, R., and Baldwin, I. T. 1997. Induced Responses to Herbivory. University of Chicago Press. Chicago

Kende, H. 1993 Ethylene biosynthesis. Annu. Rev. Plant Physiol. Plant Mol. Biol. 44:283-307.

Knoester, M., Pieterse, C. M. J., Bol, J. F., and Van Loon, L. C. 1999. Systemic resistance in Arabidopsis induced by Rhizobacteria requires ethylene-dependent signaling at the site of application. Mol. Plant-Microbe Interact. 12:720-727.

Krupnick, G. A., Avila, G., Brown, K. M., and Stephenson, A. G. 2000. Effects of herbivory on internal ethylene production and sex expression in Cucurbita texana. Funct. Ecol. 14:215-225.

Laemmli, U. K. 1970. Cleavage of structural proteins during the assembly of the head of bacteriophage T4. Nature 227:680-685.

Lau, O. L., and Yang, S. F. 1976. Inhibition of ethylene production by cobaltous ion. Plant Physiol. 58:14-117.

Laudert, D., and Weiler, E. W. 1998. Allene oxide synthase: A major control point in Arabidopsis thaliana octadecanoid signaling. Plant J. 15: 675-684.

Lawton, K. A., Potter, S. L., Uknes, S., and Ryals, J. 1994. Acquired resistance signal transduction in Arabidopsis is ethylene independent. Plant Cell 6, 581-588.

Lescot, M., Déhais, P., Thijs, G., Marchal, K., Moreau, Y., Van de Peer, Y., Rouzé, P., and Rombauts, S. 2002. PlantCARE, a database of plant cisacting regulatory elements and a portal to tools for in silico analysis of promoter sequences. Nucleic Acids Res. 30:325-327.

Lorenzo, O., Piqueras, R., Sanchez-Serrano, J. J., and Solano, R. 2003. ETHYLENE RESPONSE FACTOR1 integrates signals from ethylene and jasmonate pathways in plant defense. Plant Cell 15:165-178.

Lorenzo, O., and Solano, R. 2005. Molecular players regulating the jasmonate signaling network. Curr. Opin. Plant Biol. 8:532-540.

Marte, M., Buonaurio, R., and Dellatorre, G. 1993. Induction of systemic resistance to tobacco powdery mildew by tobacco mosaic virus, tobacco necrosis virus or ethephon. J. Phytopathol. 138:137-144.

Moeder, W., Barry, C. S., Tauriainen, A. A., Betz, C., Tuomainen, J., Utriainen, M., Grierson, D., Sandermann, H., Langebartels, C., and Kangasjärvi, J. 2002. Ethylene synthesis regulated by biphasic induction of 1-aminocyclopropane-1-carboxylic acid synthase and 1-aminocyclopropane-1-carboxylic acid oxidase genes is required for hydrogen 
peroxide accumulation and cell death in ozone-exposed tomato. Plant Physiol. 130:1918-1926.

O’Donnell, P. J., Calvert, C., Atzorn, R., Wasternack, C., Leyser, H. M. O., and Bowles, D. J. 1996. Ethylene as a signal mediating the wound response of tomato plants. Science 274:1914-1917.

Ohme-Takagi, M., Suzuki, K., and Shinshi, H. 2000. Regulation of ethylene-induced transcription of defense genes. Plant Cell Physiol. 41:1187-1192.

Pechan, T., Jiang, B.-H., Steckler, D. S., Ye, L., Lin, L., Luthe, D. S., and Williams, W. P. 1999. cDNA clones encoding cysteine proteinases from corn (Zea mays L.) callus. Plant Mol. Biol. 40:111-119.

Pechan, T., Ye, L. J., Chang, Y. M., Mitra, A., Lin, L., Davis, F. M., Williams, W. P., and Luthe, D. S. 2000. A unique 33-kD cysteine proteinase accumulates in response to larval feeding in maize genotypes resistant to fall armyworm and other lepidoptera. Plant Cell 12:10311040.

Pechan, T., Cohen, A., Williams, W. P., and Luthe, D. S. 2002. Insect feeding mobilizes a unique plant defense protease that disrupts the peritrophic matrix of caterpillars. Proc. Natl. Acad. Sci. U.S.A. 99:13319-13323.

Penninckx, I. A., Thomma, B. P., Buchala, A., Metraux, J. P., and Broekaert, W. F. 1998. Concomitant activation of jasmonate and ethylene response pathways is required for induction of a plant defensin gene in Arabidopsis. Plant Cell 10:2103-2113.

Pieterse, C. M. J., and van Loon, L. C. 1999. Salicylic acid-independent plant defence pathways. Trends Plant Sci. 4:52-58.

Price, J., Li, T. C., Kang, S. G., Na, J. K., and Jang, J. C. 2003. Mechanisms of glucose signaling during germination of Arabidopsis. Plant Physiol. 132:1424-1438.

Ritchie, S. W., Hanway, J. J., and Benson G. O. 1986. How a corn plant develops. Iowa State University of Science and Technology, Cooperative Extension Service, Special Report 48 (revised), Ames, IA, U.S.A.

Ryan, C. A. 2000. The systemin signaling pathway: Differential activation of defensive genes. Biochem. Biophys. Acta 1477:112-122.

Sakai, H., Hua, J., Chen, Q. G., Chang, C., Medrano, L. J., Bleecker, A. B., and Meyerowitz, E. M. 1998. ETR2 is an ETR1-like gene involved in ethylene signaling in Arabidopsis. Proc. Natl. Acad. Sci. U.S.A. 95:5812-5817.

Schaller, G. E., and Kieber, J. J. 2002. Ethylene. In: The Arabidopsis Book. C. R. Somerville and E. M. Meyerowitz, eds., American Society of Plant Biologists, Rockville, MD, U.S.A.

Schmelz, E. A., Alborn, H. T., Banchio, E., and Tumlinson, J. H. 2003. Quantitative relationships between induced jasmonic acid levels and volatile emission in Zea mays during Spodoptera exigua herbivory. Planta 216:665-673.
Shinshi, H., Usami, S., and Ohme-Takagi, M. 1995. Identification of an ethylene-responsive region in the promoter of a tobacco class I chitinase gene. Plant Mol. Biol. 27:923-932.

Sisler, E. C., and Serek, M. 1997. Inhibitors of ethylene responses in plants at the receptor level: Recent developments. Phys. Plant. 100:577582.

Stotz, H. U., Pittendrigh, B. R., Kroymann, J., Weniger, K., Fritsche, J., Bauke, A., and Mitchell-Olds, T. 2000. Induced plant defense responses against chewing insects. Ethylene signaling reduces resistance of Arabidopsis against cotton worm but not diamondback moth. Plant Physiol. 124:1007-1017.

Thomma, B. P., Eggermont, K., Tierens, K. F., and Broekaert, W. F. 1999. Requirement of functional ethylene-insensitive 2 gene for efficient resistance of Arabidopsis to infection by Botrytis cinerea. Plant Physiol. 121:1093-1102.

Waldbauer, G. P. 1968. The consumption and utilization of food by insects. Adv. Insect Physiol. 5:229-288.

Wang, K. L. C., Li, H., and Ecker, J. R. 2002. Ethylene biosynthesis and signaling networks. Plant Cell 14:S131-S151.

Watanabe, T., Seo, S., and Sakai, S. 2001. Wound-induced expression of a gene for 1-aminocyclopropane-1-carboxylate synthase and ethylene production is regulated by both reactive oxygen species and jasmonic acid in Cucurbita maxima. Plant Physiol. Biochem. 39:121-127.

Williams, W. P., Buckley, P. M., and Davis F. M. 1989. Combining ability for resistance in corn to fall armyworm and southwestern corn borer. Crop Sci. 29:913-915.

Williams, W. P., Davis, F. M., and Windham, G. L. 1990. Registration of Mp708 germplasm line of maize. Crop Sci. 30:757.

Winz, R. A., and Baldwin, I. T. 2001. Molecular interactions between the specialist herbivore Manduca sexta (Lepidoptera, Sphingidae) and its natural host Nicotiana attenuata. IV. Insect-induced ethylene reduces jasmonate-induced nicotine accumulation by regulating putresine $\mathrm{N}$ methyltransferases transcripts. Plant Physiol. 125:2189-2202.

Wu, C. T., and Bradford, K. J. 2003. Class I chitinase and $\beta-1,3$-glucanase are differentially regulated by wounding, methyl jasmonate, ethylene, and gibberellin in tomato seeds and leaves. Plant Physiol. 133:263-273.

Xu, Y., Chang, P. L., Liu, D., Narasimhan, M. L., Raghothama, K. G., Hasegawa, P. M., and Bressan, R. A. 1994. Plant defense genes are synergistically induced by ethylene and methyl jasmonate. Plant Cell 6:1077-1085

Zegzouti, H., Jones, B., Frasse, P., Marty, C., Maitre, B., Latché, A., Pech, J. C., and Bouzayen, M. 1999. Ethylene-regulated gene expression in tomato fruit characterization of novel ethylene-responsive and ripeningrelated genes isolated by differential display. Plant J. 18:589-600. 